\title{
Late Quaternary history of paleoseismic activity along the Hohhot Segment of the Daqingshan piedmont fault in Hetao depression zone, North China
}

\author{
Yongkang Ran, Peizhen Zhang and Lichun Chen \\ Institute of Geology, China Seismological Bureau, Beijing, China
}

\begin{abstract}
The Daqingshan Piedmont Fault (DPF) is one of the major active normal faults in the Hetao depression zone in the northern part of Ordos Block, North China. It extends in NEE direction along the Daqingshan piedmont zone in the eastern part of the depression, dipping to the south, for a length of $223 \mathrm{~km}$. The fault formed in the Eocene and underwent strong movement during the Cenozoic time. Its vertical displacement amplitude has exceeded $2400 \mathrm{~m}$ since the Quaternary. The fault can be divided into 5 active segments. Paleoseismological studies were concentrated on its western part from Baotou to Tumdzuoqi whereas the Hohhot Segment to the east was scarcely studied. To fill this gap of knowlegde, the authors carried out in-depth study on the Daqingshan piedmont fault during recent years. Excavation of trenches at Kuisu, Ulanblang, and Bakouzi sites on the Hohhot Segment of the Daqingshan piedmont fault and study of geomorphic surfaces allow us to identify and date paleoearthquakes and to evaluate the completeness of paleoseismic activity history. This was done both for the individual sites and for the entire segment since the Late Quaternary using the «method for displacement confining» along the fault and «method for correlation between multiple trenches». In this paper we present the geological loggings of two trenches at Kuisu site, provide the evidence for 6 events since $19 \mathrm{ka} \mathrm{BP}$ and the cumulative displacement amount produced by them is around $7 \mathrm{~m}$. But the cumulative displacement amount obtained from difference in heights of geomorphic surfaces is $5 \sim 5.5 \mathrm{~m}$. Results of tests using the method of displacement confining show that the event sequence revealed at this site can be considered complete. The data supplemented with information obtained in the Ulanblang and Bakouzi trenches show that 7 paleoseismic events occurred on the Hohhot Fault Segment since $19 \mathrm{ka} \mathrm{BP}$, i.e. they occurred at $18.75 \pm 0.75 \mathrm{ka}, 16.97 \pm$ $\pm 0.96 \mathrm{ka}, 14.65 \pm 0.67 \mathrm{ka}, 11.82 \pm 0.69 \mathrm{ka}, 9.45 \pm 0.26 \mathrm{ka}, 6.83 \pm 0.26 \mathrm{ka}$, and $4.50 \pm 0.23 \mathrm{ka} \mathrm{BP}$, respectively, and the average recurrence interval is $2.375 \pm 0.432 \mathrm{ka}$. These results basically reflects the history of paleoseismic activity on the fault segment in this period of time.
\end{abstract}

Key words Daqingshan piedmont fault (China) Hohhot Segment - paleoearthquakes - seismic history - completeness of paleoseismic record

\section{Introduction}

The Daqingshan Piedmont Fault (DPF) is one of the major active normal faults in Hetao

Mailing address: Dr. Yongkang Ran, Institute of Geology, China Seismological Bureau, Beijing 100029, China; e-mail: ykran@263.net depression in the northern part of Ordos Block, North China (fig. 1). A $M 7.5$ earthquake occurred on the fault in 849 A.D. An important industrial-agricultural economic zone and two major cities of Inner Mongolia Autonomous Region, Baotou and Hohhot, are distributed basically along the fault zone. Because the fault is a typical active normal fault and its movement can seriously threaten people's lives and properties in the region, many scientists have studied its paleoseismic activity, fault movement behaviors, and recurrence intervals of strong 


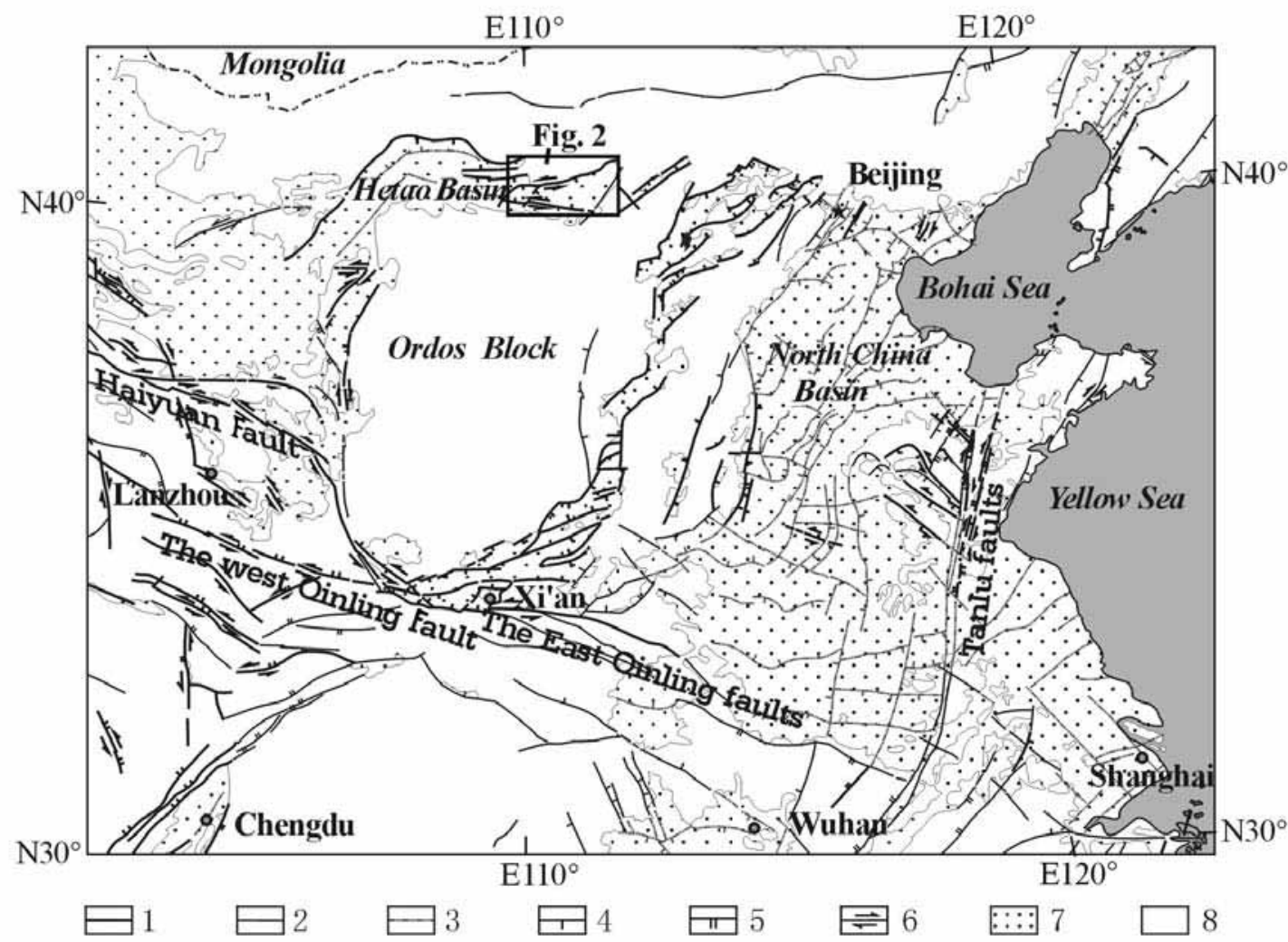

Fig. 1. Map showing active faults in North China and the position of study area: 1 - active faults in Late Pleistocene and Holocene; 2 - active faults in Early and Middle Pleistocene; 3 - hidden active faults in Quaternary; 4 - normal fault; 5 - reverse fault; 6 - strike-slip fault; 7 - Quaternary sedimentary basin; 8 - Quaternary uplifted area.

earthquakes along the fault (Research Group on Active Fault System around Ordos Block, 1988; Li et al., 1994; Wu et al., 1995; Nie et al., 1996; Jiang et al., 2001). A large number of data have been accumulated and provided a good basis for new studies. However, there exist some weakly studied problems for the fault, for example, the previous paleoseismological studies were largely concentrated on its western part from Baotou to Tumdzuoqi and less on the other segments of the fault. Are the other fault segments potentially seismogenic too? Can the revealed paleoearthquakes be considered representative of a complete history of paleoseismic activity on the fault in the Late Quaternary? If it is incomplete, how can the seismic hazard be evaluated using the available paleoseismological data? These questions led the authors to conduct a detailed study on the Daqingshan piedmont fault during recent years, in particular, on the Hohhot Segment. This paper deals with the paleoseismic events revealed along the segment since the Late Quaternary and discusses the completeness of its paleoseismic activity history.

\section{Brief geology and geomorphology}

DPF is one of three major active normal faults in the Hetao depression zone in the northern part of Ordos Block, North China. It ex- 
tends in a ENE direction, dip to the south, along the southern piedmont of Daqingshan Range for a length of $223 \mathrm{~km}$. The Daqingshan Range in the north of the DPF has been uplifted to an elevation of $1000 \mathrm{~m}$ above the Hohhot Basin, a vertical displacement of more than $2400 \mathrm{~m}$ since the Quaternary was estimated (Research Group on Active Fault System around Ordos Block, 1988). The range, consisting mainly of Achean metamorphic rocks and Jurassic debris rocks is formed by a tilted block. The southern slope of the range is far steeper than the northern slope. The Tertiary planation surface on the range top dips to the north. As the Daqingshan Range intermittently uplifted due to the fault movement, gorges were formed by creeks flowing southward, along which at least 3-4 terraces are well developed. The most striking geological-geomorphic features along the Daqingshan piedmont fault are three surfaces, which are widely distributed on the footwall of the fault. The first-step surface, formed $c a$.
8000 10000 years ago (Li et al., 1994), consists mostly of the raised alluvial fan deposits controlled by fault scarp. Its height is several to over ten meters above the present surface of the basin. The second- and third-step surfaces are mostly covered with Late Pleistocene alluvialdiluvial or alluvial-lacustrine sediments (the youngest lacustrine sediments were dated to be $23.0 \sim 26.0 \mathrm{ka} \mathrm{BP}$; Li et al., 1994) and are located at $120 \sim 170 \mathrm{~m}$ above the present basin. The piedmont tableland along the Hohhot Segment is not well preserved, but the spur surface 60-90 $\mathrm{m}$ high was found. The elevation of surface in the west of Baotou gradually decreases down to $15 \mathrm{~m}$. The fault scarps usually appear to cut the surfaces.

The DPF consists of step-like normal faults along its strike and the spatial distribution of their movement appears to have been uneven since the Late Pleistocene (Research Group on Active Fault System around Ordos Block, 1988). Li et al. (1994) claim that the DPF can

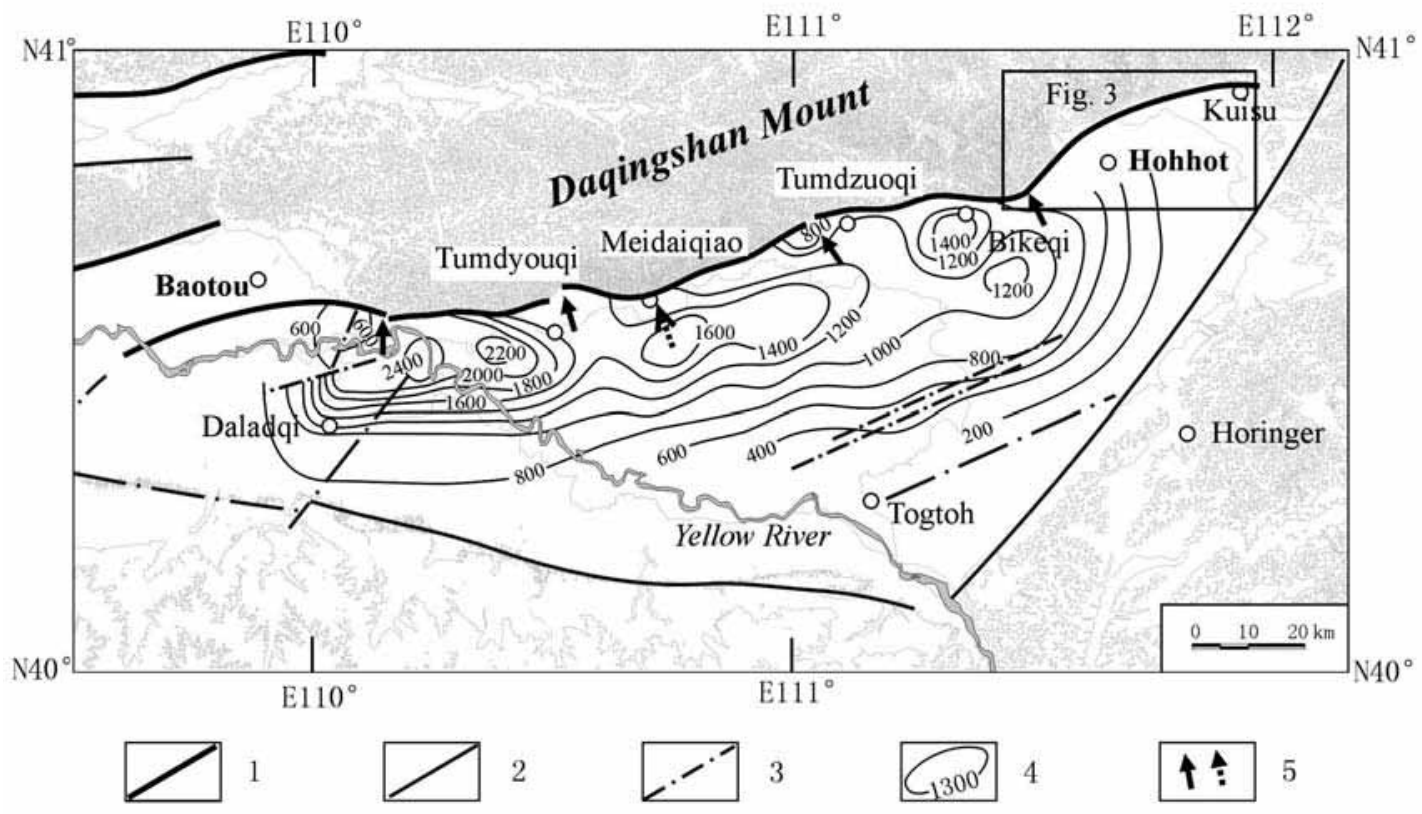

Fig. 2. Principal characteristics of the Daqingshan piedmont fault: 1 - active faults in Late Pleistocene and Holocene; 2 - pre-Pleistocene active fault; 3 - buried fault; 4 - depth contour of the Quaternary deposits; 5 - segment boundary, dotted lines were decided by predecessors, but given up now. 
be divided into 5 segments according to its geometry, kinematics, and distribution of paleoseismic events, i.e. Yellow River-Xuehaigou, Xuehaigou-Tumdyouqi, Tumdyouqi-Meidaiqiao, Meidaiqiao-Tumdzuoqi and Tumdzuoqi-Kuisu segments. Jiang et al. (2001) divided the DPF into three segments, i.e. West Baotou, BaotouTumdzuoqi, and Tumdzuoqi-Hohhot segments. The main evidence for this interpretation is that the $849, M 7.5$ earthquake rupture extended from Xuehaigou to Tumdzuoqi, and thus the three segments in the Li et al. (1994) model can be considered as a single segment. We prefer the division of the fault into 5 segments, but by introducing some changes in the the boundary locations and lengths of the segments. According to the distribution of cumulative displacement amounts reflected by the isopach of Quaternary deposits along each segment (fig. 2), we consider that the DPF should be better divided into 5 segments, the Yellow River-Xue- haigou (Baotou) Segment $37 \mathrm{~km}$ long, Xuehaigou-Tumdyouqi (West Tumdyouqi) Segment $35 \mathrm{~km}$ long, Tumdyouqi-Tumdzuoqi (West Tumdzuoqi) Segment 56 km long, TumdzuoqiUsutu (Bikeqi) Segment 49 km long, and UsutuKuisu (Hohhot) Segment 46 km long.

According to Li et al. (1994), the displacement rate since the Late Pleistocene is 4.75 $\sim 6.46 \mathrm{~mm} / \mathrm{a}$ along the West Tumdyouqi, West Tumdzuoqi and Bikeqi segments, $2.4 \sim 3.5 \mathrm{~mm} / \mathrm{a}$ along the Baotou Segment, and 2.4-3.5 mm/a along the Hohhot Segment.

\section{Trench logs at several sites and paleoseismological analysis}

Three main trenches and their supplementary trenches were excavated at the sites of Kuisu, Ulanblang and Bakouzi (fig. 3) to disclose evidence for paleoseismic events in adja-

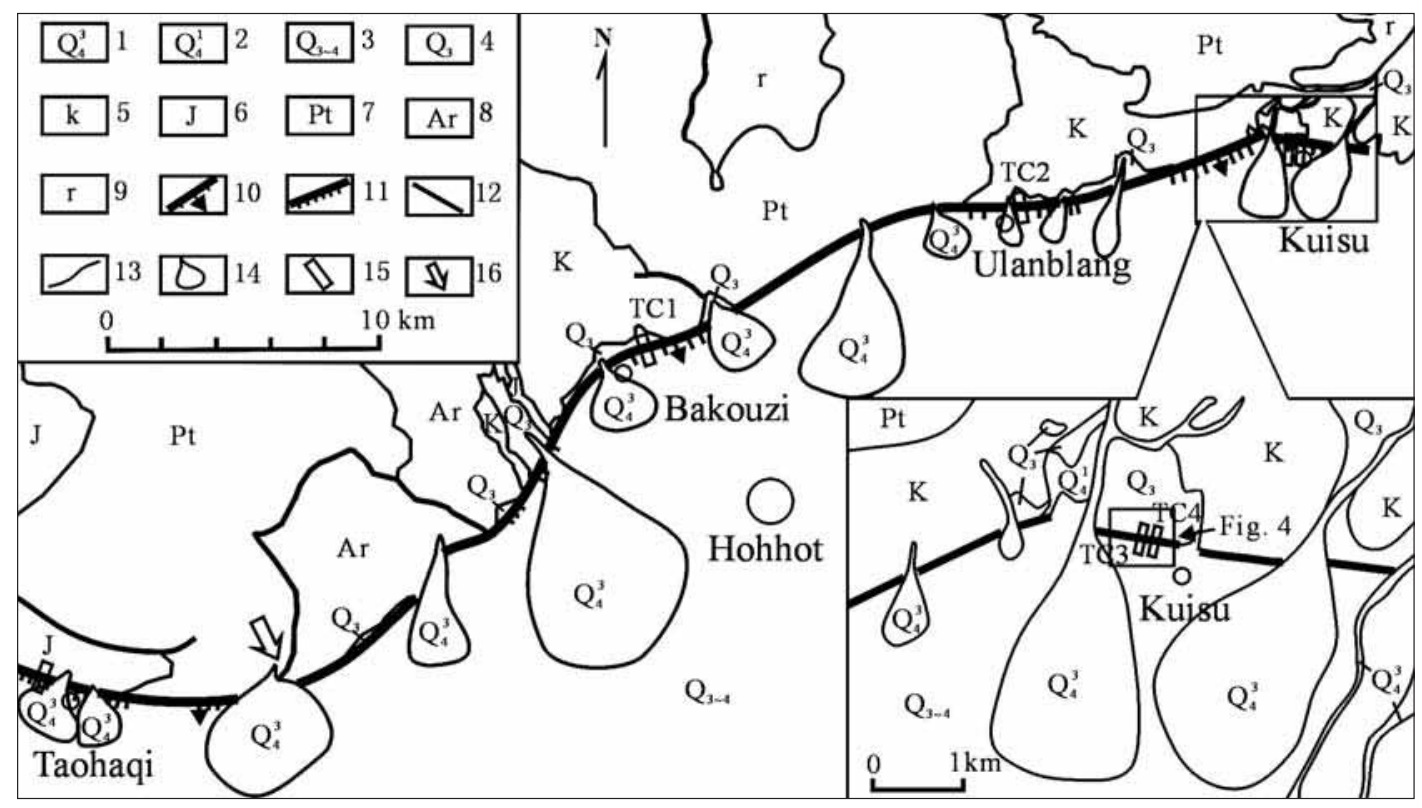

Fig. 3. Geological sketch showing the Hohhot Segment of Daqingshan piedmont fault: 1 - Upper Holocene; 2 - Lower Holocene; 3 - Upper Pleistocene to Holocene; 4 - Upper Pleistocene; 5 - Cretaceous; 6 - Jurassic; 7 Paleozoic; 8 - Archean; 9 - Granites; 10 - Late Pleistocene active normal fault; 11 - section with clear fault scarp; 12 - Quaternary Fault; 13 - geologic boundary; 14 - recent alluvial fan; 15 - location of trench; 16 - boundary between fault segments. 
cent trenches at the same site and along segments to identify the whole rupture extent.

\subsection{Kuisu site}

\subsubsection{Analysis of deposits and evidence of paleo-} seismic events exposed in the main trench (Tc3)

The excavated trenches are located in the west of Kuisu village, where the Kuisu gully runs from north to south and resulted in the formation of a huge alluvial-diluvial fan accumulated on the mountain spur (fig. 3). The alluvialdiluvial fan was offset by the DPF and its surface was abandoned on the upthrown side of the fault (fig. 4). The surface was partially destroyed by the gully of regressive erosion. It can be seen on the section cut by the gully that the tableland on the upthrown side is composed of boulders or large-sized cobbles covered by eolian or secondary loess. The downthrown side is more complicated, as some deposits are from gully terrace sediments and others are loess or secondary loess with several meters in thick-

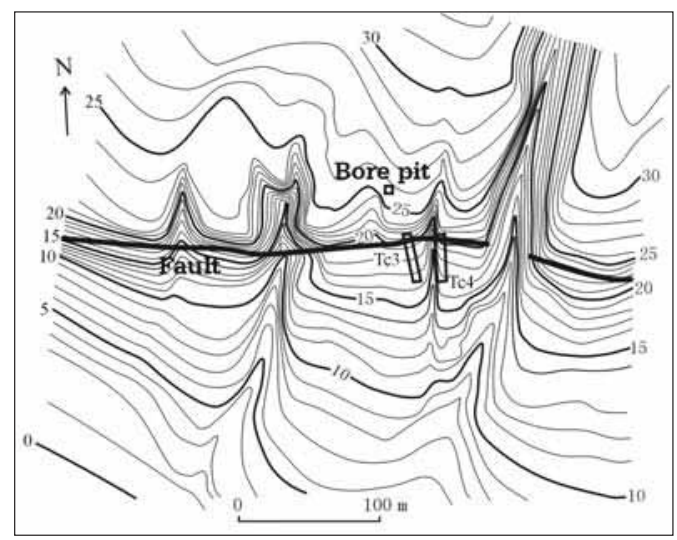

Fig. 4. Topographic map of the area west of Kuisu village: spacing between topographic contours is $1 \mathrm{~m}$; square shows bore pit for sampling, at $56 \mathrm{~cm}$ below the surface. ${ }^{14} \mathrm{C}$ sample (Kc5) from thin-layer carbonaceous sandy clay was dated to be $19990 \pm 395$ years BP; rectangle shows location of excavated trenches. ness. We attempted to reveal as many paleoseismic events as possible on the one hand, and to collect samples for ${ }^{14} \mathrm{C}$ dating on the other. A large trench (20 $\mathrm{m}$ long, $3 \mathrm{~m}$ wide, and $5 \mathrm{~m}$ deep in maximum) was excavated in front of the tableland, where the fault scarp was less disturbed by recent human activity. A supplementary trench (Tc4) was excavated very close and along the gully (20 m long and $4 \mathrm{~m}$ deep) to collect samples for ${ }^{14} \mathrm{C}$ dating where the most recent sediments were accumulated.

The sediments exposed in trench Tc3 were divided into 9 units (fig. 5). Unit 1, exposed on the upthrown side of the fault, consists of gravel layers from the stream, they show clear bedding and sorting. The grain size reaches maximum $50 \mathrm{~cm}$ and visible thickness is $4.2 \sim 4.6 \mathrm{~m}$. Unit 2 is found only on the downthrown side of the fault on the western wall of the trench. It is composed of yellow silt and sandy soil, lithologically similar to eolian loess, weakly pedogenic, corresponding to sediments on the surface. Units 3, 4, 5, 6 and 7 are only exposed on the downthrown side of the fault and lithologically are not significantly different, composed of loess and secondary loess. All these units are commonly characterized by a higher content of gravel close to the fault, variegated, and loess or brown loess clumps found near the fault and at the bases of the units, but they gradually change into pure loess or secondary loess at a distance from the fault. Obviously, they are the mixed products of accumulation in front of the scarp after faulting and during eolian sedimentation. Unit 8 covers the top of the fault and consists mainly of blackish sandy soil near the fault, but pale due to the concentration of calcium, gradually changes into loess or secondary loess at a distance from the fault. Unit 9 is composed of yellow-black sandy soil with gravel.

Five offset scarp-front deposit units possibly representing 6 paleoearthquakes can be distinguished in accordance with the above-described lithological characteristics and the distribution of strata in combination with the disturbance and dislocation of the strata by the fault (fig. 5). Unit 2 represents an ancient land surface, a sample (KT1) dated by thermoluminescene (TL) method to be $18.80 \pm 1.45 \mathrm{ka} \mathrm{BP}$ 

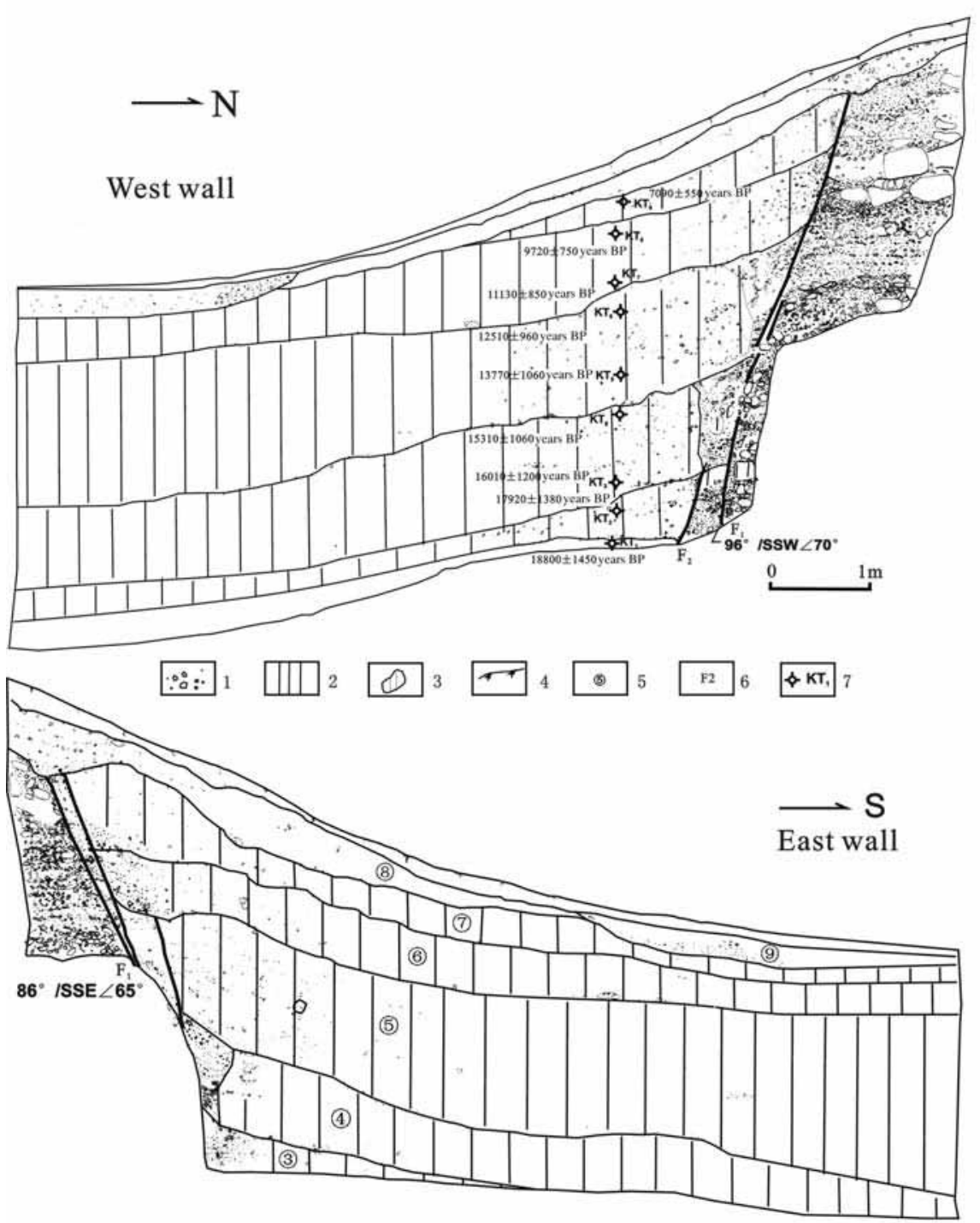

Fig. 5. Geological logging of the Kuisu large trench (Tc3): 1 - gravel; 2 - yellow sandy soil; 3 - loess or soil lumps; 4 - surface soil; 5 - stratigraphic unit and its number; 6 - fault and its number; 7 - TL sample site and its number. Stratigraphic sequence: unit 1 - gravel layer, layered and sorted; unit 2 - yellow silt and sandy soil, weakly pedogenic; unit 3 - mixed sediments of yellow sandy soil with gravel and loess or brown loess clumps, gradually changing into loess or secondary loess with distance from fault; unit 4 - yellow sandy soil, content of gravel increases near fault and at base of the unit, variegated, containing brown loess clumps and gradually changing into loess or secondary loess; units 5, 6, and 7 - mixed sediments of yellow sandy soil with gravel and loess or brown loess clumps, content of gravel increases near fault and at their base, variegated, containing loess or brown loess clumps, which gradually change into pure loess or secondary loess with distance from fault, similar to units 3 and 4 . Unit 8 - mainly pale sand, rich in calcium; unit 9 - yellow silt with small-sized gravel. 
Table I. Age values confining paleoseismic events.

\begin{tabular}{|c|c|c|c|c|c|}
\hline Trench\# & Sample\# & Material & $\begin{array}{l}\text { Dating } \\
\text { method }\end{array}$ & $\begin{array}{l}\text { Measured age } \\
(\text { years BP) }\end{array}$ & $\begin{array}{l}\text { Calib. age } \\
\text { (years BP) }\end{array}$ \\
\hline \multirow[t]{4}{*}{ TC1 } & Qc7 & Humus & ${ }^{14} \mathrm{C}$ & $9820 \pm 160$ & $10990 \pm 150$ \\
\hline & Qc8 & Humus & ${ }^{14} \mathrm{C}$ & $9270 \pm 130$ & $10230 \pm 150$ \\
\hline & Qc6 & Humus & ${ }^{14} \mathrm{C}$ & $10140 \pm 190$ & \\
\hline & Qc5 & Humus & ${ }^{14} \mathrm{C}$ & $5780 \pm 85$ & $6570 \pm 110$ \\
\hline \multirow[t]{8}{*}{ TC2 } & TW9 & Silty soil & $\mathrm{TL}$ & $19750 \pm 1520$ & \\
\hline & TW7 & Silty soil & $\mathrm{TL}$ & $15320 \pm 1180$ & \\
\hline & TW8 & Silty soil & TL & $13890 \pm 1070$ & \\
\hline & TW1 & Silty soil & TL & $10710 \pm 820$ & \\
\hline & TW2 & Silty soil & $\mathrm{TL}$ & $8110 \pm 620$ & \\
\hline & TW3 & Silty soil & TL & $7720 \pm 590$ & \\
\hline & TW4 & Silty soil & $\mathrm{TL}$ & $6490 \pm 490$ & \\
\hline & CW1 & Humus & ${ }^{14} \mathrm{C}$ & $4030 \pm 10$ & \\
\hline \multirow[t]{9}{*}{ TC3 } & KT1 & Silty soil & TL & $18800 \pm 1450$ & \\
\hline & KT2 & Silty soil & $\mathrm{TL}$ & $17920 \pm 1380$ & \\
\hline & KT3 & Silty soil & TL & $16010 \pm 1200$ & \\
\hline & KT4 & Silty soil & $\mathrm{TL}$ & $15310 \pm 1060$ & \\
\hline & KT5 & Silty soil & TL & $13770 \pm 1060$ & \\
\hline & KT6 & Silty soil & TL & $12510 \pm 960$ & \\
\hline & KT7 & Silty soil & TL & $11130 \pm 850$ & \\
\hline & KT8 & Silty soil & TL & $9720 \pm 750$ & \\
\hline & KT9 & Silty soil & $\mathrm{TL}$ & $7090 \pm 550$ & \\
\hline \multirow[t]{2}{*}{ TC4 } & WC2 & Humus & ${ }^{14} \mathrm{C}$ & $13570 \pm 140$ & \\
\hline & WC3 & Humus & ${ }^{14} \mathrm{C}$ & $9210 \pm 180$ & \\
\hline bore pit & $\mathrm{Kc5}$ & Humus & ${ }^{14} \mathrm{C}$ & $19990 \pm 395$ & \\
\hline
\end{tabular}

Notes: TL samples and ${ }^{14} \mathrm{C}$ samples were dated in the Neogeochronological Laboratory of Institute of Geology, China Seismological Bureau.

(table I). It reflects the oldest paleoseismic event occurring some time later than the age value. Then unit 3 was deposited. Unit 3 was offset by fault F2, providing clear evidence for a second event. The subsequent unit 4 covers fault F2. TL dating of samples from the top part of unit 3 and the base of unit 4 yielded age values of $17.92 \pm 1.38 \mathrm{ka} \mathrm{BP}(\mathrm{KT} 2)$ and $16.01 \pm$ $\pm 1.20 \mathrm{ka} \mathrm{BP}(\mathrm{KT} 3)$, respectively. Thus, the second paleoseismic event occurred between these two age values. The third paleoseismic event caused fault Fl to offset unit 4 and resulted in formation of a filled wedge near the fault, as found on both eastern and western walls of the trench. Then, unit 5 was accumulated and covers the filled wedge. TL samples from the top part of unit 4 and the base of unit 5 were dated to be $15.31 \pm 1.06 \mathrm{ka} \mathrm{BP}(\mathrm{KT} 4)$ and $13.77 \pm 1.06$ ka BP (KT5), respectively. The fourth event led unit 5 to be in direct contact with the fault on the western wall of the trench and a filled wedge to be developed. It expresses an offset of unit 5 by the fault on the eastern wall of the trench and unit 6 covers a branching fault. TL sample from the top of unit 5 was dated to be $12.51 \pm 0.96 \mathrm{ka} \mathrm{BP}$ (KT6). Afterwards, unit 6 was accumulated. TL sample from the base of unit 6 was dated to be $11.13 \pm 0.85 \mathrm{ka} \mathrm{BP}$ (KT7). Thus, the fourth event occurred between $12.51 \pm 0.96$ and $11.13 \pm 0.85 \mathrm{ka} \mathrm{BP}$. The fifth event is expressed as a possible dislocation of unit 6 and led to accumulation of unit 7 on both walls of the trench. This event is less contrained than the others. It is known from age values of TL samples (KT8 and KT9) from the top part of unit 6 and the middle part of unit 7 that the event occurred between $9.72 \pm 0.75 \mathrm{ka}$ $\mathrm{BP}$ and $7.09 \pm 0.55 \mathrm{ka} \mathrm{BP}$. The sixth event has 
dislocated unit 7 and then the unit 8 was accumulated. At present, only the time of the sixth event is known to be later than $7.09 \pm 0.55 \mathrm{ka}$ BP. Moreover, the traces of three later events can be found in trench Tc4 too.

We attempted to estimate coseismic displacement amount by analysis of thickness and lithological composition of scarp-front deposits. In a simple model of normal faulting, the thickness of fault-scarp colluvial wedges near the normal fault is commonly assumed to be half of the initial scarp height (McCalpin, 1996). But if the scarp-front deposits were not completely the colluvium from initial scarp, then their double thickness should be regarded as a maximum displacement amount. We measured the maximum thickness of scarp-front deposits formed by every event (measurement was done perpendicularly to bed plane and the thickness of deposits on the upper breaking point was measured for the last event). The obtained thickness of them is $0.50 \pm 0.03 \mathrm{~m}, 0.85 \pm 0.05 \mathrm{~m}, 1.1 \pm$ $\pm 0.1 \mathrm{~m}, 0.65 \pm 0.03 \mathrm{~m}, 0.8 \pm 0.3 \mathrm{~m}$, and $0.6 \pm$ $\pm 0.02 \mathrm{~m}$, respectively. We know from the above that all the scarp-front deposits formed by events disclosed in the Tc3 contain some eolian loess, except for the last event, so they are the mixed deposits of colluvial and eolian materials. Therefore, we tend to regard the thickness of scarp-front deposits formed by events $\mathrm{I} \sim \mathrm{V}$ as the minimum coseismic displacement amount, i.e. $0.50 \pm 0.03 \mathrm{~m}, 0.85 \pm 0.05 \mathrm{~m}, 1.1 \pm$ $\pm 0.1 \mathrm{~m}, 0.65 \pm 0.03 \mathrm{~m}$, and $0.8 \pm 0.3 \mathrm{~m}$, respectively. Whereas, double thickness of scarp-front deposits are regarded as the maximum coseismic displacement amount; these are $c a .1 \mathrm{~m}$, $1.7 \mathrm{~m}, 2.2 \mathrm{~m}, 1.3 \mathrm{~m}$, and $1.6 \mathrm{~m}$, respectively, and their mean values represent the inferred displacement amounts produced by the events $\mathrm{I} \sim \mathrm{V}$ at this site, i.e. $0.7 \pm 0.25 \mathrm{~m}, 1.28 \pm 0.43 \mathrm{~m}, 1.65 \pm$ $\pm 0.55 \mathrm{~m}, 0.95 \pm 0.35 \mathrm{~m}$, and $1.2 \pm 0.4 \mathrm{~m}$, respectively. Because the deposit by event VI does not contain eolian loess, double thickness of the deposit covering the fault is used to represent the inferred coseismic displacement amount, i.e. ca. $1.2 \mathrm{~m}$. Thus, the minimum cumulative displacement amount by the paleoseismic events revealed at this site is $c a .5 .1 \mathrm{~m}$ and the maximum is $c a .9 \mathrm{~m}$, mean value is $c a$. $7.03 \mathrm{~m}$.

\subsubsection{Paleoseismological analysis of supplementary trench (Tc4)}

A supplementary trench was excavated on the eastern wall of the gully east of the main trench (fig. 6). It mainly revealed part of a small graben formed by fault movement on several faults. As the trench was excavated along the

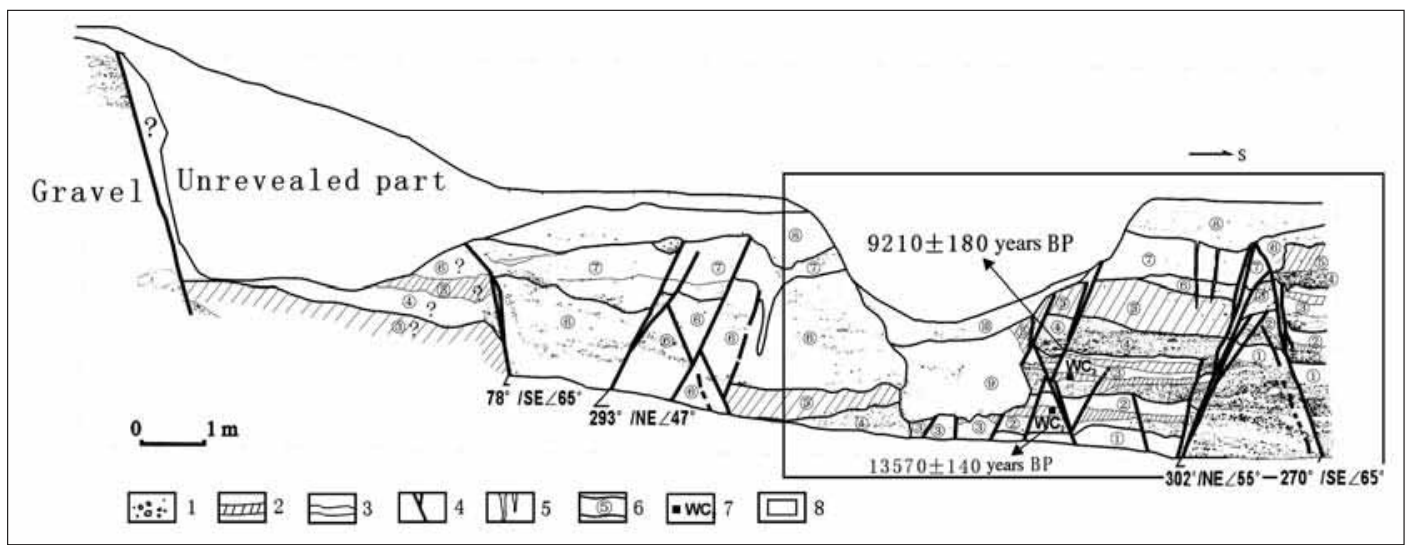

Fig. 6. Geological log of Kuisu supplementary trench (Tc4): 1 - sandy gravel; 2 - brown-black clayey sand; 3 - yellow clayey sand; 4 - fault; 5 - fissure and fillings; 6 - stratigraphic unit and its number; 7 - site of ${ }^{14} \mathrm{C}$ sample; 8 - analyzed part of the profile in detail. 
gully wall, the relation between the exposed strata and displacement is more complicated, a correlation between fault scarp and collapse wedge is not clearly found, but some characteristics of deposits in the small graben in the front of scarp can be distinguished. If the gravel layer-brown-black sandy soil-yellow sandy soil sequence is regarded as a sedimentary unit, and other sequences are stratified in terms of their lithological characteristics. A total of 10 stratigraphic units are identified. Units $1 \sim 3$ are the gravel layer-brown-black sandy soil-yellow sandy soil sequence. Unit 5 is composed of about 85 $\mathrm{cm}$ thick brown sandy soil. Unit 7 is relatively pure eolian loess. Units 9 and 10 are recently ditch-filling yellow sandy soil and sediments on the ditch surface. The units $2 \sim 5$ are characterized by deposition in a small graben in the front of the scarp and well correlated with fault movement traces. In the trench log the top part of fault cutting unit 2 is covered with unit 3 and the fault cutting unit 3 is covered with units 4 $\sim 7$, which were also offset. It indicates that at least 3 events can be distinguished in the log. ${ }^{14} \mathrm{C}$ sample (WC2) from the top part of brownblack soil of unit 2 was dated to be $13570 \pm 140$ years BP. ${ }^{14} \mathrm{C}$ sample (WC3) from the top part of brown-black soil of unit 3 was dated to be $9210 \pm 180$ years BP. It follows that 3 events occurred since $13.57 \mathrm{ka} \mathrm{BP}$, two of them between earlier than $9.21 \mathrm{ka}$ BP and $13.57 \mathrm{ka} \mathrm{BP}$, the third after $9.21 \mathrm{ka} \mathrm{BP}$. These appear to correlate well with the fourth, fifth, and sixth events revealed in trench $\mathrm{Tc} 3$.

\subsection{Ulanblang site ( $T c 2)$}

A large trench (Tc2) was excavated $(20 \mathrm{~m}$ long, $3.5 \mathrm{~m}$ wide, and $4-4.5 \mathrm{~m}$ deep) at about $400 \mathrm{~m}$ east of Ulanblang village. At this site the fault scarp is well developed and two steps of scarp can be distinguished because of gully erosion. Moreover, there is a clear change in the slope grade on the recent wide gully bottom. Here actually there are three fault scarps $\mathrm{F}$ with different heights. They are about $7.2 \mathrm{~m}$, $3.6 \mathrm{~m}$ and $1.2 \mathrm{~m}$ high, respectively. The trench Tc2 was excavated across the highest step of scarp.
The strata exposed in the Ulanblang large trench (Tc2) can be divided into 16 units (fig. 7). Units $1 \sim 3$ are exposed only on the footwall of the fault. Unit 1 consists of Cretaceous conglomerate and mudstone and units 2 and 3 consist of Late Pleistocene fluvial-lacustrine sediments. Units $4 \sim 11$ are characterized by scarpderived deposits caused by fault movement. Unit 4 was deposited near fault F1 and consists of brown-black sandy clay with gravel in a fault contact with unit 5, which is gray-yellow sandy clay with gravel and then gray-yellow sandy soil with massive structure was accumulated and formed unit 6. TL sample $\left(\mathrm{TW}_{9}\right)$ from the upper part of unit 6 was dated to be $19.75 \pm 1.52 \mathrm{ka} \mathrm{BP}$ (table I). This stratigraphic contact relation indicates that the first event revealed in the trench occurred before the deposition of unit 6 , earlier than $19.75 \pm 1.52 \mathrm{ka}$ BP. Unit 7 is a wedge-shaped calcium-rich pale deposit near fault Fl. Unit 8 is gray-yellow sandy soil with gravel in its lower part and upward becomes pedogenic brown sandy soil. It indicates that the unit was exposed at the surface for long time and then has offset and buried. Thus, it is conceivably the result of a paleoseismic event. TL sample $\left(\mathrm{TW}_{7}\right)$ from the top part of the unit 8 was dated to be $15.32 \pm$ \pm 1.18 ka BP. Later, unit 9 was accumulated, TL sample $\left(\mathrm{TW}_{8}\right)$ from its base was dated to be $13.89 \pm 1.07 \mathrm{ka} \mathrm{BP}$. It indicates that the second event disclosed in the trench occurred between $15.32 \pm 1.18 \mathrm{ka} \mathrm{BP}$ and $13.89 \pm 1.07 \mathrm{ka} \mathrm{BP}$. Unit 9 has covered the paleosol buried by event 2 and is a chaotic soil and gravel deposit, with more gravel in lower part, and calcium-rich pale deposit in middle part. Unit 9 represents a scarp-derived deposit mainly formed of colluvial material and was offset by event 3 . Soon after the event, the wedge-shaped unit 10 was formed (near faults F1 and F5). TL samples $\left(\mathrm{TW}_{8}\right.$ and $\left.\mathrm{TW}_{1}\right)$ from the base of unit 9 and the top part of unit 10 were dated to be $13.89 \pm$ $\pm 1.07 \mathrm{ka} \mathrm{BP}$ and $10.71 \pm 0.82 \mathrm{ka} \mathrm{BP}$, respectively, indicating event 3 occurring between the two age values. Event 4 caused fault F5 to offset unit 10 , as found on both eastern and western walls of the trench, which was covered with unit 11. Age value of TL samples $\left(\mathrm{TW}_{2}\right.$ and $\mathrm{TW}_{3}$ ) from the base of unit 11 and the top 


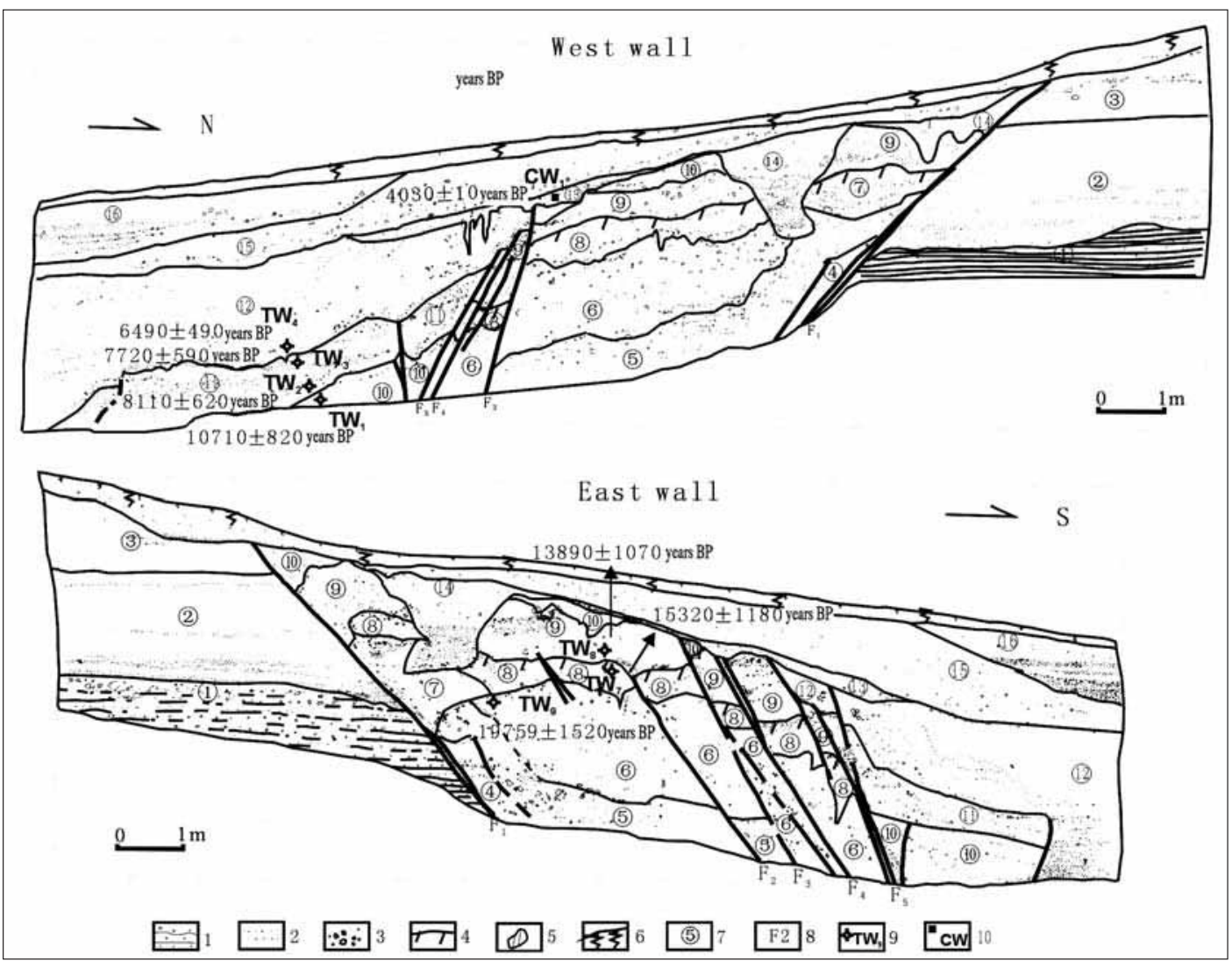

Fig. 7. Geological log of large trench (Tc2) in Ulanblang village: 1 - interlayers of conglomerate and mudstone; 2 - sand-gravel with clear layering; 3 - sandy soil with dispersed gravel; 4 - buried soil; 5 - loess or soil lumps; 6 - surface soil; 7 - stratigraphic unit and its number; 8 - fault and its number; 9 - location of TL sample and its number; 10 - location of ${ }^{14} \mathrm{C}$ sample and its number. Stratigraphic sequence: unit 1 - weathered and semi-weathered Jurassic conglomerate with grayish mudstone containing carbonized matters; unit 2 - lacustrine gray-yellow and orange-yellow silt clayey sand with interlayers of coarse sand-small-sized gravel and clayey sand; unit 3 - red clayey sand with gravel lenses; unit 4 - brown-black sandy clay with gravel; unit 5 - gray-yellow sandy clay with dispersed gravel; unit 6 - gray-yellow sandy soil with massive structure; unit 7 - gray-yellowish calcium-rich sandy soil; unit 8 - gray-yellowish sandy soil with gravel in lower part and upward becomes darkbrown sandy soil (pedogenic); unit 9 - yellow sandy soil with gravel; unit 10 - yellow sandy soil; unit 11 - sandy soil with gravel; unit 12 - brown-yellow sandy soil with dispersed gravel, brown-black and black southward; unit 13 - thin black soil; unit 14 - deposits in ditch (may be man-dug ditch); unit 15 - brown-yellow and brownblack sandy soil with dispersed gravel; unit 16 - layering and well sorted small-sized gravel bed in lower part and brown-black soil rich in humic matter in upper part.

part of unit 10 are $8.11 \pm 0.62 \mathrm{ka} \mathrm{BP}$ and $10.71 \pm$ $\pm 0.82 \mathrm{ka} \mathrm{BP}$, respectively. Thus, the event occurred between $10.71 \pm 0.82 \mathrm{ka} \mathrm{BP}$ and $8.11 \pm$ $\pm 0.62 \mathrm{ka} \mathrm{BP}$. Unit 11 was offset by event 5 , as found on the west wall of the trench. Unit 12 was mainly accumulated near fault F5. Age values of TL samples $\left(\mathrm{TW}_{3}\right.$ and $\mathrm{TW}_{4}$ ) from the top part of unit 11 and the base of unit 12 indicate the event occurring between $7.72 \pm 0.59$ $\mathrm{ka} \mathrm{BP}$ and $6.49 \pm 0.49 \mathrm{ka} \mathrm{BP}$. Unit 12 was off- 
set by event 6 and faults F3 F5 and was covered with sediments of unit 13 and later. ${ }^{14} \mathrm{C}$ sample $\left(\mathrm{CW}_{1}\right)$ from unit 13 was dated to be $4030 \pm$ \pm 10 years BP. Part of unit 13 filled the cracks in unit 12, reflecting its accumulation following event 6 . It indicates that the event occurred slightly earlier than $4030 \pm 10$ years BP.

\subsection{Bakouzi site (Tcl)}

The Bakouzi trench (Tc1) was excavated at about $1 \mathrm{~km}$ east of Bakouzi. Correlative geomorphic surfaces at this site are clearly different in elevation, though the fault scarp is poorly preserved due to recent human activity. At a mountain spur, terraces on a series of gullies flowing toward the basin were offset. Elevation of the highest terrace is more than $10 \mathrm{~m}$ above gully beds, the third-order terrace is 5-6 m, and that of the second-order terrace is 3-4 $\mathrm{m}$. The sediments on the second-order terrace were offset by fault at many sites. We analyzed the exposure of the gully east of Bakouzi (fig. 8).

The strata exposed on the gully wall can be divided into 7 stratigraphic units. Unit 1 is red clay, earlier sediment. Units $2 \sim 4$ are gully deposits . ${ }^{14} \mathrm{C}$ sample $\left(\mathrm{Q}_{\mathrm{C}} 8\right)$ from the base of unit 4 was dated to be $10230 \pm 150$ years BP (table I) after dendrochronological correction. Units $5 \sim 7$ represent scarp-derived deposits mainly formed of colluvial material. Unit 5 is a wedge-shaped deposit formed in a fissure in front of the scarp and is composed of mixed gravel and sandy soil. ${ }^{14} \mathrm{C}$ sample $\left(\mathrm{Q}_{\mathrm{C}} 7\right)$ from its top brown-black soil was dated to be $10990 \pm 150$ years BP after dendro-

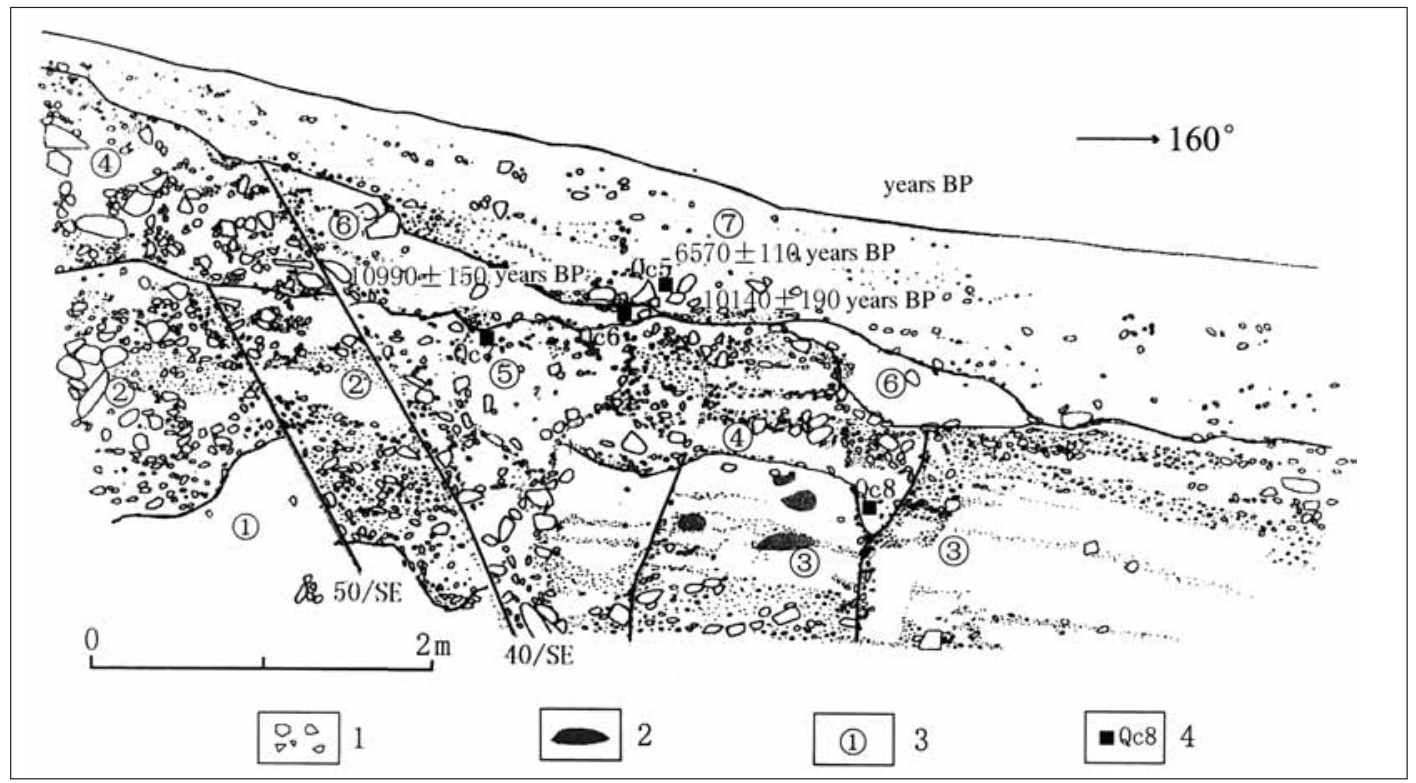

Fig. 8. Geological log of the trench (Tc1) excavated on gully wall east of Bakouzi: 1 - gravel; 2 - soil lumps; 3 - stratigraphic unit and its number; 4 - location of ${ }^{14} \mathrm{C}$ sample and its number. Stratigraphic sequence: unit 1 red clay locally containing gravel; unit 2 - gravel bed intercalating a brown-yellow sandy clay layer; unit 3 interlayers of small-sized gravel and sandy clay with brown-black soil clumps; unit 4 - gravel and sandy soil; unit 5 - wedge-shaped deposit of mixed gravel and sandy soil; unit 6 - colluvial wedge, more gravel in lower part and brown-black soil with gravel in upper part; unit 7 - brown-black sandy soil intercalating a gravel layer, more cobbles in base part and black soil containing more humic matter between gravels. 
chronological correction. Unit 6 is a scarp-derived colluvial wedge, with more gravel in its lower part and brown-black soil with gravel in the upper part. ${ }^{14} \mathrm{C}$ sample $\left(\mathrm{Q}_{\mathrm{C}} 6\right)$ from its top part was dated to be $10140 \pm 190$ years BP (without dendrochronological correction). Unit 7 is brown-black sandy soil intercalating a gravel layer and covers the fault. Cobbles are more concentrated at the base of the unit and, meanwhile, black humic matter was more found between the cobbles. ${ }^{14} \mathrm{C}$ sample $\left(Q_{C} 5\right)$ from black soil at the base of the unit was dated to be $6570 \pm 110$ years BP after dendrochronological correction.

The above-described lithologic characteristics of the stratigraphic units and their structural relations with faults indicate that 3 paleoseismic events can be distinguished in the trench. The earliest event offset the deposits up to unit 3, then unit 4 was accumulated in the gully. The second event offset unit 4, resulting in the formation of mixed deposit of colluvial gravel and sandy soil in the lower part (or cleft in filled wedge), i.e. unit 5, and deposit in upper part of the colluvial wedge, i.e. unit 6 . The third event offset unit 6 and led unit 4 on footwall of the fault to be in a fault contact with unit 6 on the hanging wall. Age value of ${ }^{14} \mathrm{C}$ sample from the base of unit 4 is slightly higher than that from the upper part of unit 5, the colluvial material of which might come from the older strata. Therefore, it is inferred from dating results of the described statigraphic sequence that the first event occurred earlier than $10990 \pm$ \pm 150 years $\mathrm{BP}$, the second event was later than $10230 \pm 150$ years BP, and the third event was earlier than $6570 \pm 110$ years BP.

\section{The completeness of paleoseismic activity history}

The completeness of paleoseismic activity history along a fault is crucial for understanding the sequence of a fault and for a correct estimation of future seismic hazard. At present, no tested method for the evaluation of the completeness of paleoseismic activity history has been presented. But according to the characteristics of surface ruptures produced by normal faults and their evolution, we propose to use methods for «confining displacement amount» and for «correc- tion between events in many trenches» to determine the completeness of paleoseismic activity history along the fault segment.

\subsection{Method for confining displacement amount}

Many studies (Wallace, 1977; Bucknam and Anderson, 1979; Hanks, et al., 1984; McCalpin, 1987; Deng and Liao, 1996) highlighted that in addition to the direct determination of amount of displacement of the same marker horizon on both sides of a fault, the difference in elevation of the correlative geomorphic surface on both sides of a fault is a good indicator reflecting cumulative displacement. Thus, both observations can be used as a measure for cumulative displacement amount along the fault in a given time period. The method for confining displacement is based on the measurement of the cumulative displacement produced by the paleoseismic events recognized in the trench and that cumulated the same site for the same time interval. If the results obtained using both the methods fit, the paleoseismic history for this time interval can be considered complete.

The difficulty in using this technique is mainly related to the approach to correctly estimate the different types of displacement. Detailed quantitative studies of elevation difference of geomorphic surfaces produced by normal fault (Wallace, 1977; Deng et al., 1984; Ran et al., 1992, 1996) indicate that in most cases, the elevation difference of geomorphic surfaces obtained in field surveys is equal to (when the geomorphic surface is in a stable environment, the upper and lower primary surfaces are intact) or less than the real cumulative displacement amount along a fault since the formation of geomorphic surfaces (at least only $2 / 3$ of the real displacement; in fact the geomorphic surface on the upthrown side may have been eroded in the long-term whereas on the downthrown side partial filling may have occurred. Moreover, it should also be considered that except for the coseismic displacement directly obtained from offset sediments, the displacement amount obtained by other methods has uncertainties, especially when the coseismic displacement is obtained by measuring the double thickness of 
the colluvial wedge or different height of gully terraces. Considering these uncertainties, whatever method is used to estimate the cumulative displacement of a geomorphic surface, this is expected to be a minimum.

Figure 9 presents a graph of time versus slip accumulation. An area with fluctuating value enclosing the range of the measured height of the geomorphic surface is shown. If this fluctuating displacement of geomorphic surfaces truly reflects the real displacement amount along the fault, comparing it to the coseismic displacement can provide insights on the completeness of the paleoseismic record. When the cumulative displacement is approximately equal to or larger than the displacement in the fluctuating area, then the paleoseismic activity history can be considered complete (fig. 9 case A and B). On the contrary, if the coseismic cumulative displacement is lower than that in the fluctuating zone, then the paleoseismic record appears to be incomplete (fig. 9 case C).

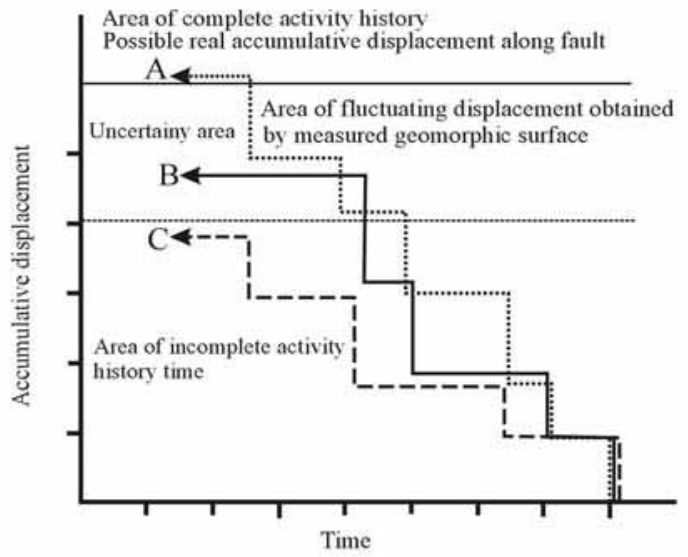

Fig. 9. Conceptual scheme for determination of the completeness of paleoseismic activity history from displacement amount. Stepped line with arrow indicates an assumed revealed paleoseismic activity history. Line A, extending into the completeness area, shows a complete activity history; line B, into the uncertainty area, remains to be further determined by other methods; line $\mathrm{C}$, into the incompleteness area, indicates a revealed incomplete paleoseismic activity history.

\subsection{Method for correlation between events in many trenches}

The method for correlation between events in many trenches is another useful method for decreasing the potential incompleteness of recognized paleoseismic events on the same segment caused by uneven distribution and different preservation degree of surface rupture traces at a single site produced by paleoearthquakes. The essence of the method is principally consistent with that of the «progressive confining method» for correlation between paleoearthquake occurrence times (Mao and Zhang, 1995). The basis for the method is that a single trench site is not enough to define a complete paleoseismic record and, as far as it is possible, it is recommended to investigate more than one site. Even if the ruptures produced by some events did not extend to one site, or were removed by erosion, evidence of the missing event can be derived from different sites. It is also possible to use many trenches for gathering more information supplementing each other, so that any event which occurred along the segment was not missing.

For this method, it is assumed that several trenches were excavated along a fault segment and the paleoseismic events revealed in the trenches are different in number, but some events found in different trenches overlap each other in their age values. Thus, by using a progressive confining method we can constrain in age some events having only their upper- or lower-limit age value determined or having their upper- and lower-age limit within their corresponding time intervals and then can better determine the age of these paleoseismic events.

\subsection{Completeness of paleoseismic activity history}

Identification of the completeness of paleoseismic activity history using the two abovedescribed methods follows the principle that the first is to use the method for confining displacement to determine whether the events revealed in each trenched site are complete and then to use the method for correlation between events in many trenches for supplementing and correc- 
ting the paleoseismic activity history along the fault segment.

\subsubsection{Test of the completeness of paleoseis- mic activity history revealed in Kuisu trenches}

Critical in the method for confining displacement amount is that the time of the oldest event should be equal to the time when the geomorphic surface was formed and offset. Study on the regional geomorphic surfaces disclosed that a lacustrine tableland formed 26-23 ka BP is widely developed in Hetao Region (Li et al., 1994; Wu et al., 1995). Then another two or three diluvial tablelands developed. In the boundary zone between Shanxi, Hebei and Inner Mongolia, the Late Quaternary diluvial tablelands were formed in the ranges $3 \sim 0 \mathrm{ka}, 10 \sim 7.5 \mathrm{ka}$, 13.5-10.3 ka, and 18.7-15.6 ka BP (Xu et al., 1996). Stratigraphic correlation of the deposits on the tablelands along the Hohhot Segment suggests that the geomorphic surfaces at the Kuisu trench sites were formed later than the lacustrine tableland surface, approximately in $18.7 \sim 15.6 \mathrm{ka} \mathrm{BP}$. The age of ${ }^{14} \mathrm{C}$ sample from a thin-layer carbonaceous sandy clay at $56 \mathrm{~cm}$ depth below the geomorphic surface at the Kuisu site is $19990 \pm 395$ years BP, representing basically the formation time of the geomorphic surface. It corresponds roughly to the time when the oldest event were revealed in the trenches. Therefore, the identification of the completeness of paleoseismic events at the two sites by using the method for confining displacement amount is feasible.

Six paleoseismic events were revealed in the trenches (Tc3, Tc4) at Kuisu site on the Hohhot Segment. The measured geomorphic surface shows displacement of $5 \sim 5.5 \mathrm{~m}$, while the cumulative displacement obtained from colluvial wedges is $5.1 \mathrm{~m}$ in minimum and $9 \mathrm{~m}$ in maximum, and is taken to be $7.03 \mathrm{~m}$ produced by paleoearthquakes. The cumulative displacement produced by the paleoearthquakes is larger than that measured from geomorphic surface. The paleoseismic activity history revealed at this site by using method for confining displacement amount is complete (fig. 10a-c).
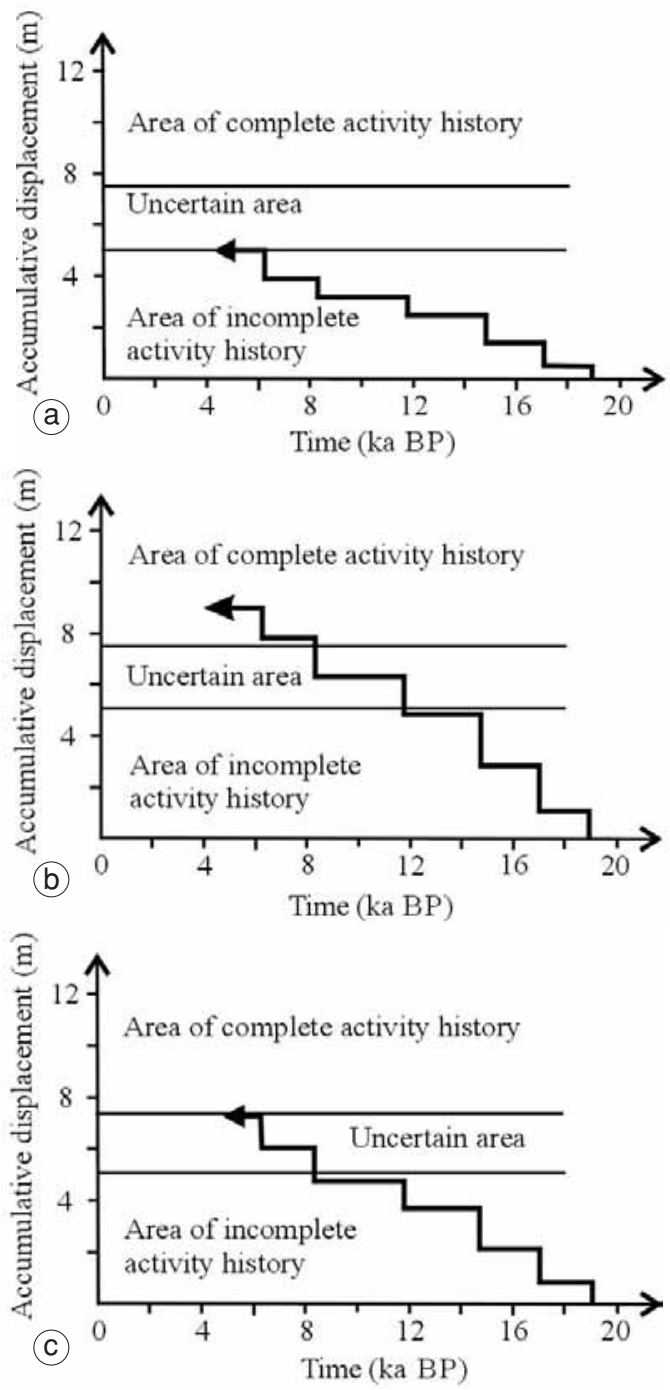

Fig. 10a-c. Scheme showing the application of the displacement confining method for identifing the completeness of paleoseismic activity history at Kuisu site. Stepped line with arrow indicates the paleoseismic activity history: a) shows confining result by using the minimum displacement; b) shows confining result by using the maximum displacement; c) shows confining result by using the mean displacement. Figure 10a-c shows that even the minimum cumulative displacement does not fall inthe incompleteness area, and both the mean and maximum cumulative displacement fall in the completeness area. On this basis the paleoseismic events revealed at Kuisu site are considered to be complete. 


\subsubsection{Correlation between paleoseismic events along the fault segment}

It is clear that the above-described three sites on the fault segment are different in tectonic positions and geomorphic surfaces where the trenches were excavated, thus, the number of paleoseismic events revealed in the trenches and age values of dated samples fluctuate (fig. 11).

It can be found in fig. 11 that 6 paleoseismic events revealed in Kuisu trench Tc3 (Kiusu 2 in fig. 11) yielded well confined their age values. 6 paleoseismic events were revealed in Ulanblang trench $\mathrm{Tc} 2$, but the second from the last event does not have its confined age value, but it can be deduced by correlation from the upper-limit age value of the third event and chronological information obtained in Kuisu trench Tc3, i.e. the age values of the two earliest events in the two trenches are approximately equal. The difference is that the latest event in Ulanblang trench occurred in little earlier than 4000 years BP. This event was not found in Kuisu trench Tc3 and other trenches. The events revealed in Kuuisu trench Tc4 and in Bakouzi trench Tc1 are fewer in number, but these events and their age values supplemented those in Kuisu trench Tc3 and Ulanblang trench Tc2. In general, the paleoseismic events reveal-

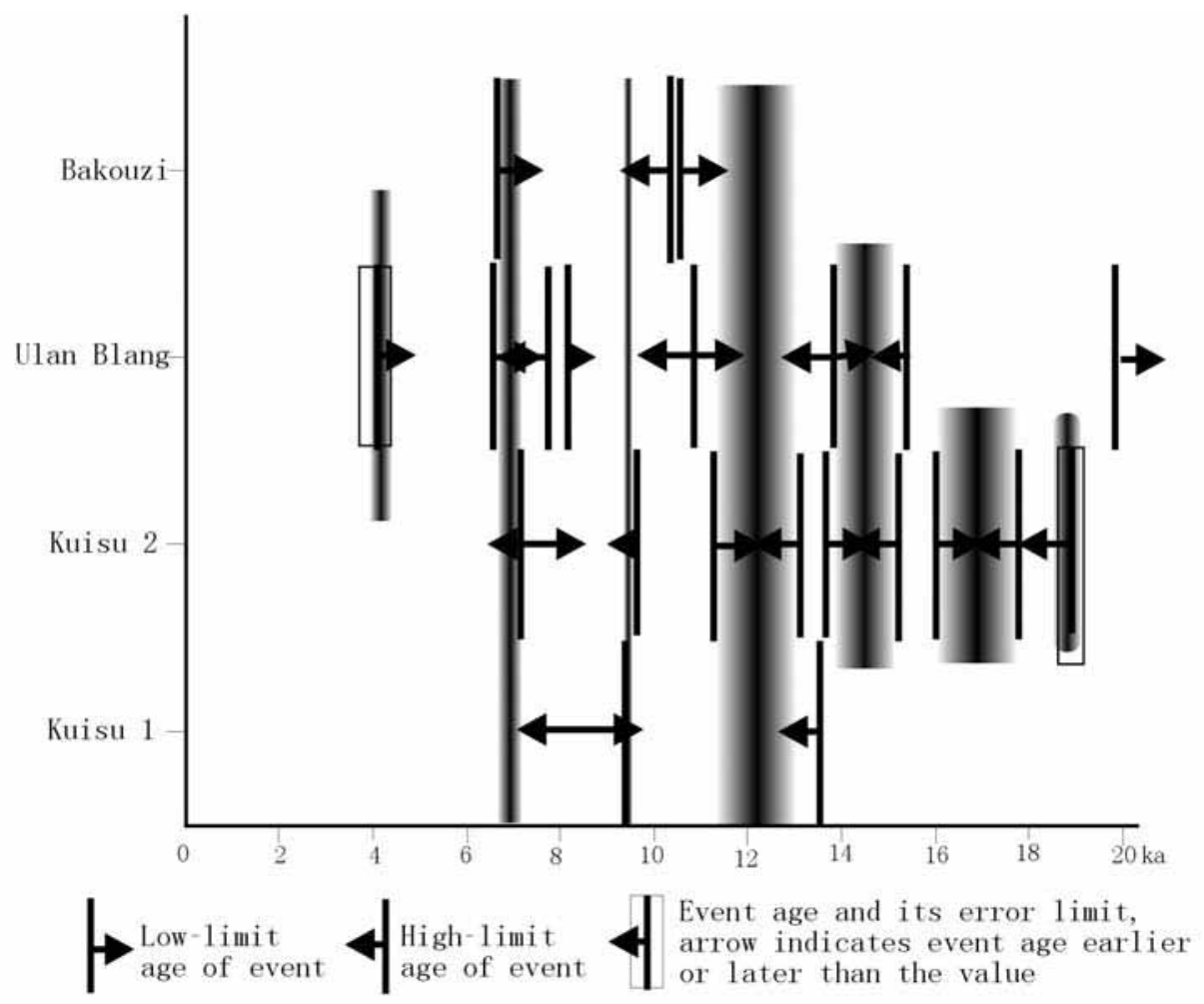

Events found in many trenches and its dated age range

Fig. 11. Correlation between paleoseismic events at different sites on the Hohhot Segment of the Daqingshan piedmont fault. 
ed in 4 trenches and their age values are confined within 7 time windows. It indicates that in all 7 paleoseismic events occurred on the Hohhot Segment since about $19 \mathrm{ka}$ BP, i.e. they occurred in $18.75 \pm 0.75 \mathrm{ka}, 16.97 \pm 0.96 \mathrm{ka}, 14.65 \pm 0.67$ $\mathrm{ka}, 11.82 \pm 0.69 \mathrm{ka}, 9.45 \pm 0.26 \mathrm{ka}, 7.41 \pm 0.315$ $\mathrm{ka}$, and $4.50 \pm 0.23 \mathrm{ka} \mathrm{BP}$, respectively. This would suggest an average recurrence interval of $2375 \pm 432$ years.

It is clear that by using correlation between events found in many trenches, the events and their age values revealed in 4 trenches can be corrected and supplemented to each other, so we can eventually determine 7 paleoseismic events which represent the seismic activity history along the Hohhot Fault Segment since about 19 ka BP. Moreover, the latest event may be missing at Kuisu site, as the site is located near the boundary of the studied fault segment. Paleoseismic traces in the Bakouzi trench were removed by erosion from gully, so the loss of seismic events is expected.

\section{Conclusions}

Excavation of trenches at Kuisu, Ulanblang, and Bakouzi sites on the Hohhot Segment of the Daqingshan piedmont fault and detailed study of geomorphic surfaces permitted us to identify the completeness of paleoseismic activity history at single sites and on the fault segment using methods for confining displacement amount and method for correlation between events in many trenches and provide an improved dataset.

Two trenches at Kuisu site have mutually confirmed the revealed 6 seismic events since 19 ka BP. The cumulative displacement amount produced by these events is around $7 \mathrm{~m}$ and that obtained from difference in height of geomorphic surfaces is $5 \sim 5.5 \mathrm{~m}$. The result of the test using method for confining displacement amount shows that the paleoseismic events revealed at this site is complete.

The Ulanblang and Bakouzi trenches revealed 6 and 3 events, respectively. The second event from last in Ulanblang trench has no age value limit, so its age can be determined from the upper-limit age value of the third event and chronological information obtained in Kuisu trench. The latest event in Ulanblang trench occurred a little earlier than 4000 years BP, but this event was not found in Kuisu and other trenches. Events revealed in Bakouzi trench are fewer in number, but the events and their age values in this trench well supplement those in Kuisu and Ulanblang trenches. The integration of data from different trenches at 3 sites shows that a total of 7 paleoseismic events occurred on the Hohhot Segment since 19 ka BP, i.e. they occurred in $18.75 \pm 0.75 \mathrm{ka}, 16.97 \pm 0.96 \mathrm{ka}$, $14.65 \pm 0.67 \mathrm{ka}, 11.82 \pm 0.69 \mathrm{ka}, 9.45 \pm 0.26$ $\mathrm{ka}, 7.41 \pm 0.315 \mathrm{ka}$, and $4.50 \pm 0.23 \mathrm{ka} \mathrm{BP}$, respectively, and the average recurrence interval is $2375 \pm 432$ years. It basically reflects the paleoseismic activity history on the fault segment during this period of time.

\section{Acknowledgements}

This work is supported under one of the $\mathrm{Na}$ tional Major Basic Theoretical Research Projects Mechanism and Prediction of Strong Earthquake of China (G1998040701). We are especially grateful to Dr. Daniela Pantosti for her valuable suggestions about the paper. Thanks to Prof. Defu Shen, Dr. Zhujun Han, Prof. Fa Yang, Wengshen Guo, Bo Hu, and Zhiming Liu for favorable discussions during this project.

\section{REFERENCES}

BuCKNAM, R.C. and R.E. ANDERSON (1979): Estimation of fault scarp age from a scarp-height-slope-angle relationship, Geology, 7, 11-14.

Deng, Qidong and Yuhua Liao (1996): Paleoseismology along Helanshan piedmont fault, North-Central China, J. Geophys. Res., 101 (B3), 5873-5893.

Deng, Qidong, Wang Yipeng, Yuhua LiaO, Zhang Weioi and Li Mengluan (1984): Collapse wedges by fault scarps and Holocene history of movement along Helanshan piedmont fault, Chin. Sci. Bull., 9, 557-560 (in Chinese with English abstract).

Hanks, T.C., R.C. BucKnam, K.R. LAJoie and R.E. WALlaCE (1984): Modification of wave-cut and faulting-controlled landforms, J. Geophys. Res., 89 (B7): 5771-5790.

Jiang, Wali, Xiao Zhenmei, Wang Huanzhen and Gong FUHUA (2001): Segmentation character of seismic surface ruptures of the piedmont active fault of Mt. Daqingshan, Inner Mongolia, Seismol. Geol., 23 (1), 24-34 (in Chinese with English abstract). 
Li, Ke, Wu Weimin, Yang Fa, Nie Zongsheng, Guo WENSHENG and MA BAOQI (1994): A study on segmentation of Daqingshan piedmont active fault, in Research on Active Faults in China, edited by Seismogeological Subcommission of Chinese Seismological Society (Seismological Press, Beijing), 102-113 (in Chinese)

Mao, Fengying and Zhang Peizhen (1995): Method for progressive confining of paleoseismic events and paleoseismological study of major fault zone in Northern Xinjiang, in Research on Active Faults (Seismological Press, Beijing), 4, 153-164 (in Chinese with English abstract).

MCCALPIN, J.P. (1987): Geologic criteria for recognition of individual paleoseismic events in extensional environments, in Directions in Paleoseismicity, Proceedings of Conference $X X X I X$, edited by A.J. CRONE and E.M OMDAHL, U.S. Geol. Surv. Open-File Rep. 87-683, 102-114.

McCalpin, J.P. (1996): Paleoseismology (Academic Press, New York), pp. 583.

Nie, Zongsheng, Jiang Wali and Wu Weimin (1996): Study on Holocene paleoearthquakes in large trenches on the western segment of Daqingshan piedmont fault zone, Inner Mongolia, in Research on Active Faults (Seismological Press, Beijing), 5, 125-135 (in Chinese with English abstract).

Ran, Yongkang, FANG Zhonging, Wang JingBo, Li ZhiYI, L RUCHENG, ZHANG CHONGLI and ZHANG DAWEI (1992): Late Quaternary movement behavior along Shenzhuang-
Haopjiapo Segment of northern border fault of Huai-Zhu Basin, in Research on Active Faults (Seismological Press, Beijing), 2, 152-162 (in Chinese with English abstract).

Ran, YongKang, Fang Zhonguing, Duan Ruitao, Li ZhiYi, Wang Jingbo, Yang Zhe, Ji FenguU and Li JiAnPING (1996): Recurrence model of paleoearthquakes along Baying Segment of the northern marginal fault of Fanshan Basin in Hebei Province, Earthquake Res. China, 10 (1), 87-100

Research Group on Active Fault System around Ordos BLOCK (1988): Active Fault System around Ordos Block, State Seismological Bureau (Seismological Press, Beijing), (in Chinese).

WaLlace, R.E. (1977): Profiles and ages of young fault scarps, North-Central Nevada, Bull. Geol. Soc. Am., 66, 1267-1278.

Wu, Weimin, Li Ke, Ma Baod, Yang Fa and Guo WENSHENG (1995): Study on Holocene paleoearthquakes in large composite trench on the Daqingshan piedmont fault, in Research on Active Faults (Seismological Press, Beijing), 4, 123-132 (in Chinese with English abstract).

Xu, Xiwei, Nobuyuki Yonekury, Yasuhiro Suzuki, Qidong Deng, Yipeng Wang, AKIRA TAKeuci and CUNYU WANG (1996): Geomorphic study on Late Quaternary irregular favelting along the northern piedmont of Liulengshan Range, Shanxi Province, China Seismol. Geol., 18 (2), 169-181 (in Chinese with English abstract). 
